\title{
Chemistry and mineralogy of clay minerals in Asian and Saharan dusts and the implications for iron supply to the oceans
}

\author{
G. Y. Jeong ${ }^{1}$ and E. P. Achterberg ${ }^{2}$ \\ ${ }^{1}$ Department of Earth and Environmental Sciences, Andong National University, Andong 760-749, Republic of Korea \\ ${ }^{2}$ GEOMAR Helmholtz Centre for Ocean Research, Kiel, 24148 Kiel, Germany
}

Correspondence to: G. Y. Jeong (jearth@anu.ac.kr)

Received: 3 June 2014 - Published in Atmos. Chem. Phys. Discuss.: 17 June 2014

Revised: 21 October 2014 - Accepted: 21 October 2014 - Published: 27 November 2014

\begin{abstract}
Mineral dust supplied to remote ocean regions stimulates phytoplankton growth through delivery of micronutrients, notably iron (Fe). Although attention is usually paid to $\mathrm{Fe}$ (hydr)oxides as major sources of available Fe, Fe-bearing clay minerals are typically the dominant phase in mineral dust. The mineralogy and chemistry of clay minerals in dust particles, however, are largely unknown. We conducted microscopic identification and chemical analysis of the clay minerals in Asian and Saharan dust particles. Cross-sectional slices of dust particles were prepared by focused ion beam (FIB) techniques and analyzed by transmission electron microscopy (TEM) combined with energy dispersive X-ray spectroscopy (EDXS). TEM images of FIB slices revealed that clay minerals occurred as either nanothin platelets or relatively thick plates. Chemical compositions and lattice fringes of the nano-thin platelets suggested that they included illite, smectite, illite-smectite mixed layers, and their nanoscale mixtures (illite-smectite series clay minerals, ISCMs) which could not be resolved with an electron microbeam. EDXS chemical analysis of the clay mineral grains revealed that the average $\mathrm{Fe}$ content was $5.8 \%$ in nano-thin ISCM platelets assuming $14 \% \mathrm{H}_{2} \mathrm{O}$, while the Fe content of illite and chlorite was 2.8 and $14.8 \%$, respectively. In addition, TEM and EDXS analyses were performed on clay mineral grains dispersed and loaded on micro-grids. The average $\mathrm{Fe}$ content of clay mineral grains was 6.7 and $5.4 \%$ in Asian and Saharan dusts, respectively. A comparative X-ray diffraction analysis of bulk dusts showed that Saharan dust was more enriched in clay minerals than Asian dust, while Asian dust was more enriched in chlorite. Clay minerals, in particular nanocrystalline ISCMs and Fe-rich chlorite, are probably important sources of Fe to remote ma-
\end{abstract}

rine ecosystems. Further detailed analyses of the mineralogy and chemistry of clay minerals in global mineral dusts are required to evaluate the inputs of Fe to surface ocean microbial communities.

\section{Introduction}

Primary productivity in high-nitrate low-chlorophyll (HNLC) regions of the world's ocean has been an important topic because of the roles of this process in regulating atmospheric carbon dioxide levels over glacial-interglacial timescales (Boyd et al., 2000, 2004; Bopp et al., 2003; Jickells et al., 2005; Formenti et al., 2011). Iron (Fe) is a controlling micronutrient for phytoplankton growth in HNLC regions, with deep winter mixing (Tagliabue et al., 2010) and long-range transport of continental aerosols (including mineral dust and anthropogenic aerosols) being key $\mathrm{Fe}$ sources for surface water microbial communities. In addition, the dust-derived $\mathrm{Fe}$ supply to low-nitrate low-chlorophyll (LNLC) regions of the oceans has been shown to control dinitrogen fixation (Moore et al., 2009; Schlosser et al., 2014). Therefore, interest has grown in recent years regarding atmospheric aerosol transport, inputs to the surface ocean, and the subsequent dissolution of $\mathrm{Fe}$ from aerosols (Desboeufs et al., 2001; Jickells and Spokes, 2001; Hand et al., 2004; Guieu et al., 2005; Meskhidze et al., 2005; Baker and Jickells, 2006; Buck et al., 2006, 2010; Cwiertny et al., 2008; Journet et al., 2008; Mahowald et al., 2009; Shi et al., 2009, 2011; Aguilar-Islas et al., 2010; Baker and Croot, 2010; Fu et al., 2010; Johnson et al., 2010; Paris 
et al., 2010; Trapp et al., 2010; Formenti et al., 2011; Rubin et al., 2011; Takahashi et al., 2011; Sholkovitz et al., 2012).

Iron dissolution from aerosols has been represented by fractional Fe solubility ( $\% \mathrm{FeS}$ ), and varies strongly depending on the aerosol source (Mahowald et al., 2005; Sholkovitz et al., 2012). Sholkovitz et al. (2012) compiled total Fe loading $\left(\mathrm{Fe}_{\mathrm{T}}\right)$ and \% FeS for a global-scale set of aerosol samples, and found a hyperbolic trend in the $\% \mathrm{FeS}$ as a function of $\mathrm{Fe}_{\mathrm{T}}$, which was explained by the mixing of mineral dusts of high $\mathrm{Fe}_{\mathrm{T}}$ and low $\% \mathrm{FeS}$ and anthropogenic aerosols of low $\mathrm{Fe}_{\mathrm{T}}$ and high \% FeS. However, mineral dust is an important supply of bioavailable Fe to the remote ocean, particularly during dust events originating from desert sources. Ito and Feng (2010) demonstrated using model simulations that, compared to Asian dust, soluble Fe from combustion sources contributed a relatively small amount to the soluble Fe supply to the North Pacific Ocean during spring periods. An enhancement of dust \%FeS occurs during long-range transport. The factors responsible for this increase in $\% \mathrm{FeS}$ are not yet fully understood, and include the type of Fe-bearing minerals of dust and their reactivity (Cwiertny et al., 2008; Journet et al., 2008), the photoreduction of Fe in dust particles (Siefert et al., 1994; Hand et al., 2004; Fu et al., 2010), reactions between dust particles and water during cloud processing (Desboeufs et al., 2001; Shi et al., 2009), reactions with acidic gases in the atmosphere (Zhuang et al., 1992; Meskhidze et al., 2003), and changes in particle size during long-range transport (Jickells et al., 2005; Baker and Croot, 2010).

Information regarding dust mineralogy enables the $\% \mathrm{FeS}$ of mineral dust to be better understood, as highlighted by Cwiertny et al. (2008) after an extensive literature review. The mineralogical factors related to $\% \mathrm{FeS}$ include solubility, reactivity with atmospheric acids, grain size, Fe content, and the Fe oxidation state of the minerals. Despite numerous articles on the measurements of \%FeS (Sholkovitz et al., 2012, and references therein), the modeling of dust input (Mahowald et al., 2005, 2009; Johnson and Meskhidze, 2013), and the determinations of the aqueous geochemistry of $\mathrm{Fe}$ (Baker and Croot, 2010, and references therein), basic data are still lacking on the properties of Fe-bearing minerals in dust. Iron oxides/hydroxides are an important source of available Fe. However, the quantities of Fe (hydr)oxides in mineral dust are much lower than the quantity of Fe-bearing silicates. Mineralogical analyses have shown that clay minerals are the most abundant phases followed by quartz, feldspars, and calcite in the long-range transported dusts (Glaccum and Prospero, 1980; Avila et al., 1997; Jeong 2008; Jeong et al., 2014). The crystal structures of clay minerals can accommodate a significant quantity of $\mathrm{Fe}$ in their octahedral sites. Thus, both the clay minerals and Fe (hydr)oxides should be considered when investigating their roles in Fe availability (Raiswell and Canfield, 2012). Journet et al. (2008) reported a higher Fe solubility of clay minerals compared with Fe oxides, emphasizing the significant role of clay minerals in $\mathrm{Fe}$ availability. However, in the experiments performed by Journet et al. (2008), dissolution work was conducted for a limited set of clay minerals and Fe (hydr)oxides obtained from rocks. Clay minerals in atmospheric dust particles have diverse origins and a wide range of chemical compositions and particle sizes, depending upon the lithology, geological setting, and physical/chemical weathering process in their source regions. The contribution of clay minerals to $\mathrm{Fe}$ availability should be considered on the basis of the physical and chemical characteristics of the different clay mineral types in the natural dust. For example, the Fe content of clay minerals in dust for modeling and dissolution experiments is typically not known. The separate determination of the Fe content of each clay mineral species is almost impossible for bulk dust because of the agglomeration of many silicate mineral grains (Falkovich et al., 2001; Shi et al., 2005; Jeong, 2008; Jeong and Nousiainen, 2014; Jeong et al., 2014). This is in contrast to the exact determination of $\mathrm{Fe}$ content in the form of $\mathrm{Fe}$ (hydr)oxides using an established selective extraction procedure, such as the method of Mehra and Jackson (1960). However, the chemical composition of submicron grains of clay minerals can be determined by energy dispersive X-ray spectrometry (EDXS) of fluorescent X-ray induced by an electron microbeam. EDXS attached to a transmission electron microscope (TEM) is an excellent technique for the chemical and physical characterization of individual clay mineral grains.

In this study, we report the mineral species, nanoscopic occurrence, and chemical compositions of the clay mineral grains in individual Asian and Saharan dust particles obtained by the combined application of TEM and EDXS. Analyses of clay minerals mixed in particles were conducted on cross-sectional slices of individual dust particles prepared by focused ion beam (FIB) milling. Clay mineral grains loaded on micro-grids by a conventional procedure were also analyzed by TEM and EDXS. We furthermore present the mineral compositions of bulk dusts obtained by X-ray diffraction (XRD) analysis.

\section{Dust samples and methods}

Asian dust events were observed on 17 March 2009, 20 March 2010, 31 March 2012, and 18 March 2014 in the Republic of Korea. The dust outbreaks and subsequent migration of the Asian dusts were traced using dust index images derived from satellite remote sensing, which indicated the source of the four dust events in the Gobi desert of southern Mongolia and northern China $\left(30^{\circ}-46^{\circ} \mathrm{N}, 90^{\circ}-110^{\circ} \mathrm{E}\right)$ and their migration to the east across the Republic of Korea. Details of the synoptic conditions during the dust outbreaks and migration of these events were provided in Jeong et al. (2014). The peak concentrations of particulate matter less than $10 \mu \mathrm{m}$ in diameter $\left(\mathrm{PM}_{10}\right)$ were $428,1788,220$, and 
$378 \mu \mathrm{g} \mathrm{m}^{-3}$ in the $2009,2010,2012$, and 2014 dust events, respectively (Korea Meteorological Administration, 2014).

The Asian dusts were sampled using a Thermo Scientific high-volume total suspended particulate (TSP) sampler fitted with Pallflex teflon-coated borosilicate glass-fiber filters $\left(8 \times 10\right.$ in.) or Whatman ${ }^{\circledR}$ No. 1441-866 cellulose filters. The 2012 dust was sampled on a mountain peak at Deokjeok Island ( $190 \mathrm{~m}$ a.s.l., $\left.37^{\circ} 13^{\prime} 59^{\prime \prime} \mathrm{N}, 126^{\circ} 08^{\prime} 57^{\prime \prime} \mathrm{E}\right)$ off the western coast of the Republic of Korea for $24 \mathrm{~h}$ (09:00, 31 March-08:00, 1 April) at a flow rate of $250 \mathrm{~L} \mathrm{~min}^{-1}$. The 2009, 2010, and 2014 Asian dusts were sampled using the same procedure on the roof of a four-story building at Andong National University $\left(36^{\circ} 32^{\prime} 34^{\prime \prime} \mathrm{N}, 128^{\circ} 47^{\prime} 56^{\prime \prime} \mathrm{E}\right)$ over a $12 \mathrm{~h}$ period (09:00-21:00, 17 March 2009, 20:00-08:00, 19 March 2010, and 10:00-22:00, 18 March 2014).

Saharan dust samples were collected at the Cape Verde Atmospheric Observatory on the island of São Vicente, Cabo Verde $\left(16^{\circ} 51^{\prime} 50^{\prime \prime} \mathrm{N}, 24^{\circ} 52^{\prime} 03^{\prime \prime} \mathrm{W}\right)$ in the eastern North Atlantic Ocean. Dust was sampled on Sterlitech polypropylene membrane filters ( $47 \mathrm{~mm}$ diameter, $0.4 \mu \mathrm{m}$ pore size) using a low-volume aerosol sampler installed at the top of a $30 \mathrm{~m}$ tower in the period from 7 November 2007 to 14 March 2008 (Carpenter et al., 2010). The total volume of samples for the individual filters ranged from 50 to $100 \mathrm{~m}^{3}$ at flow rates of 20-30 $\mathrm{L} \mathrm{min}^{-1}$ for a period of 3-5 days.

$\mathrm{X}$-ray diffraction (XRD) analysis was conducted to obtain information on the mineral composition of bulk samples using a Rigaku Ultima IV diffractometer. A portion of the filter was cut and immersed in methanol in a $10 \mathrm{~mL}$ glass vial. The filter was agitated in an ultrasonic bath to remove dust particles from the filter. During the agitation, dust particles were disaggregated into clay minerals and other silicate grains. The suspension was sieved through 270-mesh sieve to remove cellulose fibers and dried on the glass plate. Then, dust was collected by razor blade. Several milligrams of dust samples $(2-10 \mathrm{mg})$ were loaded on the $3 \mathrm{~mm} \times 4 \mathrm{~mm}$ cavity of an aluminum plate. The analytical conditions were $60 \mathrm{~s}$ of counting per $0.03^{\circ}$ step in the scan range of $3-65^{\circ} 2 \theta, \mathrm{Cu}$ $\mathrm{K} \alpha$ radiation, and $45 \mathrm{kV} / 35 \mathrm{~mA}$. Because the quantity of the samples was small, the patterns obtained were not suitable for precise quantification. Thus, the compositional analysis was deemed semi-quantitative. Mineral compositions were derived using a SIROQUANT software package (version 4). Since intensity loss was significant in the lower angle region due to the small sample size irradiated with X-rays, the high angle region $\left(24.5-65^{\circ} 2 \theta\right)$ was used for the simulation of the observed XRD pattern. After the XRD analysis of the bulk dusts, the samples were subjected to ethylene glycol and heat treatments for detailed identification of clay minerals. The samples were wetted with water, smeared, and dried on a glass slide, and subsequently treated with ethylene glycol vapor at $60^{\circ} \mathrm{C}$ in a desiccator for 2 days followed by heating at $350^{\circ} \mathrm{C}$ for $30 \mathrm{~min}$.

Electron-transparent thin slices of dust particles (2009, 2012, and 2014 Asian dusts; 28-31 December, 2007, 18-23
January, 23-26 February, 29 February-4 March, 12-14 March, 2008 Saharan dusts) were prepared for TEM analysis of clay minerals. Hereafter, the term "particle" refers to individual solid objects suspended in the atmosphere, while the term "grain" refers to the constituents of the particles. Thin slices (ca. $100 \mathrm{~nm}$ in thickness) of about ca. $6 \mu \mathrm{m} \times 6 \mu \mathrm{m}$ size were cut from dust particles using a SII NanoTechnology SMI3050TB and a JEOL JIB4601F FIB instrument for the Asian and Saharan dusts. Prior to using the FIB, the dust particles were transferred onto adhesive carbon film and characterized using a JEOL JSM 6700F field emission gun scanning electron microscope (SEM) equipped with an Oxford EDXS system at $5 \mathrm{kV}$ acceleration voltage and $8 \mathrm{~mm}$ working distance after being coated with platinum for electrical conductivity. Dust particles were selected for FIB work on the basis of mineralogical characteristics identified by SEM-EDXS analysis as reported in Jeong (2008) and Jeong et al. (2014). Individual Asian dust particles could be selected and prepared as thin slices by FIB milling because the particles were sufficiently separated from each other on the filters. However, the Saharan dusts considered in this study were highly concentrated and aggregated on the filters. Thus, the original atmospheric particles for FIB milling could not be identified with confidence. However, the purpose of the TEM analysis undertaken in this study was not to reveal the structures of individual original dust particles as reported by Jeong and Nousiainen (2014), but to analyze the chemistry and mineralogy of clay mineral grains. Thus, we prepared thin slices using FIB milling from the Saharan dust samples.

Clay-mineral grains loaded on micro-grids were also prepared for investigation of Asian (2009, 2010, 2012, and 2014) and Saharan (7-9 November, 13-14 December, 28-31 December 2007, 18-23 January, 29 February-4 March, 12-14 March 2008) dust. The clay mineral grains suspended in methanol were loaded on to 200-mesh $\mathrm{Cu}$ micro-grids covered with a carbon-coated lacey formvar support film by immersing the micro-grids in the suspension with tweezers and subsequent drying on filter paper. Every electron-transparent grain encountered during the movement of stage was analyzed by EDXS.

The TEM instruments used in this study were a JEOL JEM $2100 \mathrm{~F}$ field emission gun STEM at $200 \mathrm{kV}$, a JEOL JEM 3010 TEM for high-resolution imaging, and a JEOL JEM 2010 TEM equipped with an Oxford ISIS EDXS system. Minerals in the FIB slices were identified on the basis of lattice fringe images, electron diffraction, and EDXS. General chemical formulas of minerals identified in this study are given in the Supplement Table 1. Digital images of the microstructures and lattice fringes were recorded using a Gatan digital camera and processed with a Gatan DigitalMicrograph $^{\circledR}$. To obtain the elemental compositions of clay minerals, the X-ray counts of $\mathrm{Si}, \mathrm{Al}, \mathrm{Fe}, \mathrm{Mg}, \mathrm{Ti}$, $\mathrm{K}$, and $\mathrm{Ca}$ were converted to weight $\%$ (wt $\%$ ) of the elements using the quantification procedures given by Cliff and Lorimer (1975). The $k$-factors of the elements for the con- 

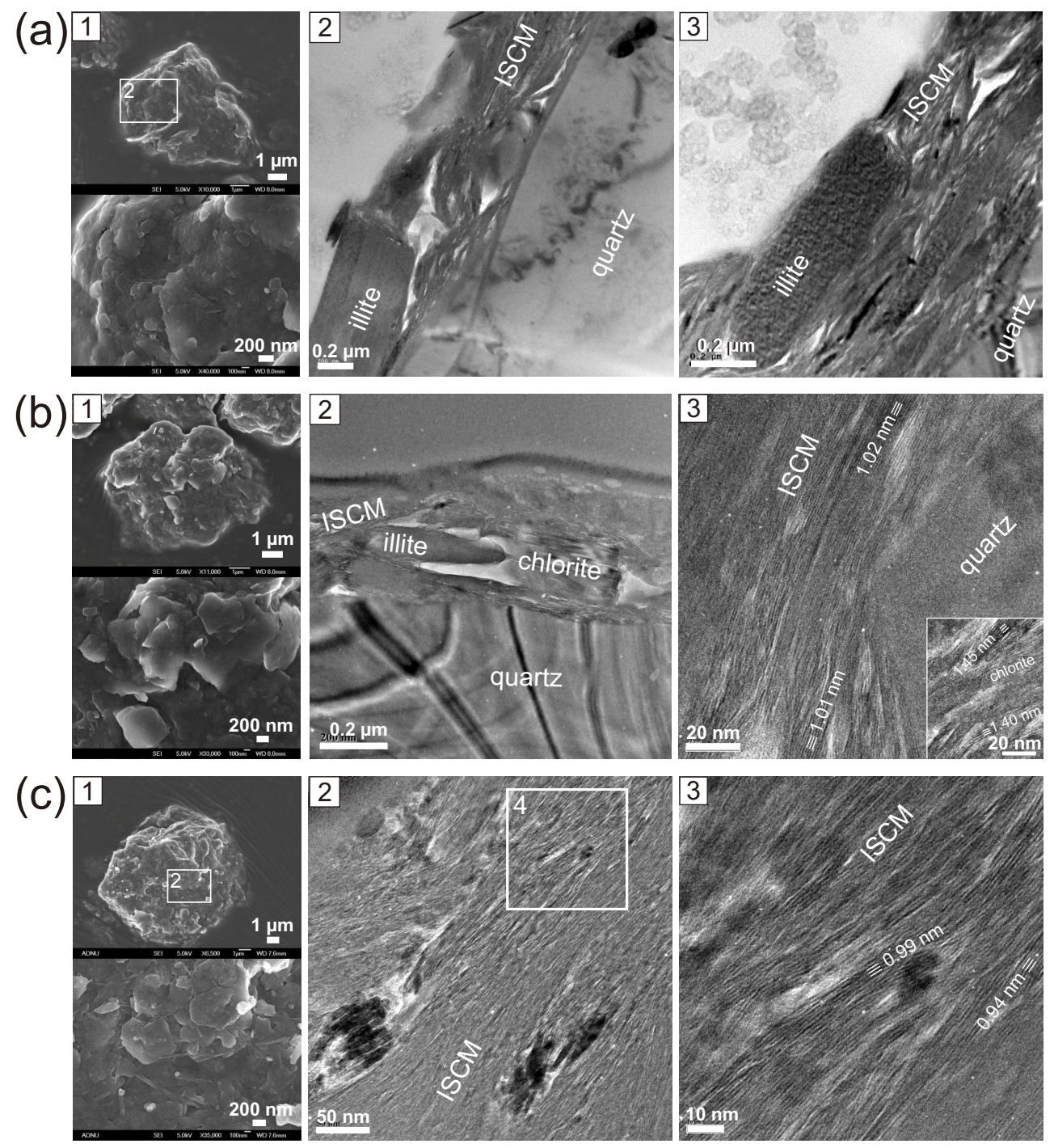

Figure 1. Occurrence of clay minerals in three Asian dust particles $(\mathbf{a}, \mathbf{b}, \mathbf{c})$. Panel 1 in each particle consists of two SEM images of the original particle (low and high magnifications). Panels 2 and 3 are TEM images of the cross-sectional FIB slice prepared from the particle in panel 1.

version were obtained from an analysis of the FIB slices prepared from biotite and plagioclase of known composition occurring in the Palgongsan granite (Jeong, 2000).

TEM-EDXS analysis often requires a small beam size down to $\sim 50 \mathrm{~nm}$ to determine the chemical composition of clay minerals that are mixed with other minerals. The Xray generation volume is small due to the thin nature of the FIB slices $(\sim 100 \mathrm{~nm})$ and small analysis area. High-quality quantitative analysis requires at least 10000 counts of each peak for the ideal specimens of large thin and resistant phases (Williams and Carter, 2009). However, such an ideal analytical condition was not obtained for the clay mineral grains, which were very sensitive to the electron beam because of their structural water, disorder, and nanocrystallinity. To minimize electron beam damage of the clay mineral grains, the electron dose was reduced by setting the spot size to four. $\mathrm{X}$-rays of $\mathrm{Si}, \mathrm{Al}, \mathrm{Fe}, \mathrm{Mg}$, $\mathrm{Ti}, \mathrm{K}$, and $\mathrm{Ca}$ were counted for $100 \mathrm{~s}$. For clay grains loaded on the micro-grids, $0.5-2 \mu \mathrm{m}$ grains produced sufficient $\mathrm{X}$-ray photons for analysis, while submicron thin clay grains (ca. $<0.5 \mu \mathrm{m}$ ) did not. The total $\mathrm{X}$-ray counts of those elements in ISIS EDXS system were ca. 30000 for the analysis of clay mineral grains loaded on the grid, and ca. 15000 for the analysis of FIB specimens. The detection limits for these elements were ca. $0.1 \mathrm{wt} \%$. For Asian dust samples, we conducted 206 analyses of clay minerals in the 50 FIB slices prepared from 50 dust particles, and 514 analyses of clay mineral grains loaded on the microgrids. For Saharan dust, we conducted 116 analyses in the 10 FIB slices prepared from 10 particles, and 356 analyses of clay mineral grains loaded on micro-grids. In the calculation 
of elemental wt \%, the total $\mathrm{H}_{2} \mathrm{O}$ content of clay minerals was assumed to be $14 \mathrm{wt} \%$, which is the average $\mathrm{H}_{2} \mathrm{O}$ content of illite and smectite provided in Table II and Table XXVII of Weaver and Pollard (1975).

\section{Results and discussion}

\subsection{Occurrence of clay minerals in dust particles}

\subsubsection{Asian dust}

SEM images reveal micron-size platy grains of clay minerals on the surface of Asian dust particles (Fig. 1a-1, b-1, and c1). TEM images of cross-sectional FIB slices show that clay mineral plates coat the surface of quartz (Fig. 1a-2, a-3, b-2, and b-3), or are agglomerated (Figs. 1c-2 and 3). Clay mineral grains were classified into two groups: (1) rather thick, compact grains of illite (Fig. 1a-2, a-3, and b-2), chlorite (Fig. 1b-2), and kaolinites (not shown here); and (2) loose chaotic, sub-parallel nano-thin platelets (Fig. 1a-2, a-3, b-2, b-3, c-2, and c-3), which display lattice fringes of ca. $1.0 \mathrm{~nm}$ (Figs. 1b-3 and 1c-3) and contained the interlayer cations $\mathrm{K}$ and $\mathrm{Ca}$. The nano-thin platelets were arranged in sub-parallel patterns to form a fine matrix with the inclusions of thick and compact clay minerals (Fig. 1a-2, a-3, and b-2). The loose, curved lattices (Fig. 1b-3 and c-3) of nano-thin plates are in contrast to the compact, straight lattices of larger plates of illite (Fig. 2a), chlorite (Fig. 2b), and kaolinite (Fig. 2c).

Larger compact grains of smectite were not found in the TEM observations of FIB slices in this study. However, smectite has previously been identified by the XRD analysis of Asian dust treated with ethylene glycol (Jeong, 2008). Thus, smectite is expected to be present in the form of nano-thin platelets of smectite or illite-smectite mixed layers. Nano-thin clay mineral platelets displaying $10 \AA$ lattice fringes were the major form of the clay minerals in the Asian dusts. Their varying $\mathrm{K}$ and $\mathrm{Ca}$ contents suggest a close mixture and mixed-layering of illite and smectite because $\mathrm{K}$ is predominantly assigned to the cation fixed in the interlayer of illite, while $\mathrm{Ca}$ is assigned to the exchangeable cation of smectite (Jeong et al., 2004). The mixtures and mixedlayering of illite and smectite unit layers are common in natural geological environments as a result of chemical weathering in soils and the low temperature diagenesis of sediments (Weaver, 1989; Środoń, 1999). However, even using the lattice-fringe imaging, unambiguous distinction was not possible between illite and smectite unit layers mixed at the nano scale because hydrated smectite (unit layer thickness of $1.4-1.6 \mathrm{~nm}$ ) had become dehydrated and had contracted to a unit layer of ca. $1.0 \mathrm{~nm}$ thickness under the high vacuum in the TEM chamber. Thus, the nanoscale mixtures of nanothin platelets with ca. $1.0 \mathrm{~nm}$ lattice fringes and containing $\mathrm{K}$ and $\mathrm{Ca}$ in varying ratios are collectively referred to here as illite-smectite series clay minerals (ISCMs) which are prob- ably mixtures/mixed-layers of illite and smectite in varying ratios. Although thick smectite grains were not observed, illite occurred as thick compact grains (Fig. 1a-2, a-3, and b-2) as well as nano-thin ISCMs. Chlorite also occurred as nanothin plates (Fig. 1b-3) in a close association with ISCMs.

TEM images of the clay mineral grains dispersed on the micro-grids are presented in Fig. 3. Micron-size ISCM plates have diffuse outlines and granular micro-textures due to nano-size subgrains (Fig. 3a-1 and a-2), which are compared to the sub-parallel group of nano-thin ISCM plates observed in the cross-sectional FIB slices (Fig. 1). The electron diffraction pattern shows turbostratic stacking of nano-size subgrains (Fig. 3a-3). However, the discrete illite grain in Fig. 2a-4 has a platy morphology with a clear grain boundary similar to the large compact grains of discrete illite in Fig. 1a-2, a-3, and b-2. The morphology and micro-textures of kaolinite grains (Fig. 3a-5) are similar to those of ISCM grains, with diffuse outlines and granular micro-textures due to the nano-size subgrains. Weathered chlorite plates consist partly of subgrains (Fig. 3b-6).

\subsubsection{Saharan dust}

The TEM images of FIB slices prepared from three clayrich particles are presented in Fig. 4. The particles are dense (Figs. 4a-1) or porous (Figs. 4b-1 and c-1) agglomerates of nano-thin platelets that are arranged in sub-parallel anastomosing patterns (Fig. 4a-2, b-2, and c-2). Lattice fringes of ca. $1 \mathrm{~nm}$ indicate the common occurrence of ISCMs (Fig. 4a3, b-3, and c-3). Larger compact grains of illite and chlorite are found in the ISCM matrix (Figs. 5a). Compact dense biotite grain grades to kaolinite as shown in Fig. $5 \mathrm{~b}$ and c. Biotite kaolinitization is a common process in the weathering environment (Dong et al., 1998; Jeong, 2000; Jeong and Kim, 2003).

TEM images of the clay mineral grains dispersed on the micro-grids show illite plates with clear outlines (Fig. 3b1) and ISCMs with diffuse outlines (Fig. 3b-2). The kaolinite plates have a hexagonal shape (Fig. 3b-3), indicating the higher crystallinity of kaolinite in Saharan dust, which is in contrast to the irregular kaolinite plate with a diffuse outline identified in Asian dust (Fig. 3a-5). Another feature of the Saharan dust distinguishing it from the Asian dust is the occurrence of elongated grains of palygorskite (inset in Fig. 3b$3)$.

\subsection{Fe content of the clay minerals}

\subsubsection{Asian dust}

EDXS analyses were carried out for two types of clay minerals identified from the TEM analysis of FIB slices: subparallel groups of thin platelets and individual thick grains. Undertaking EDXS analysis in a selective manner for each nano-thin plate was impossible due to the limit of the mini- 

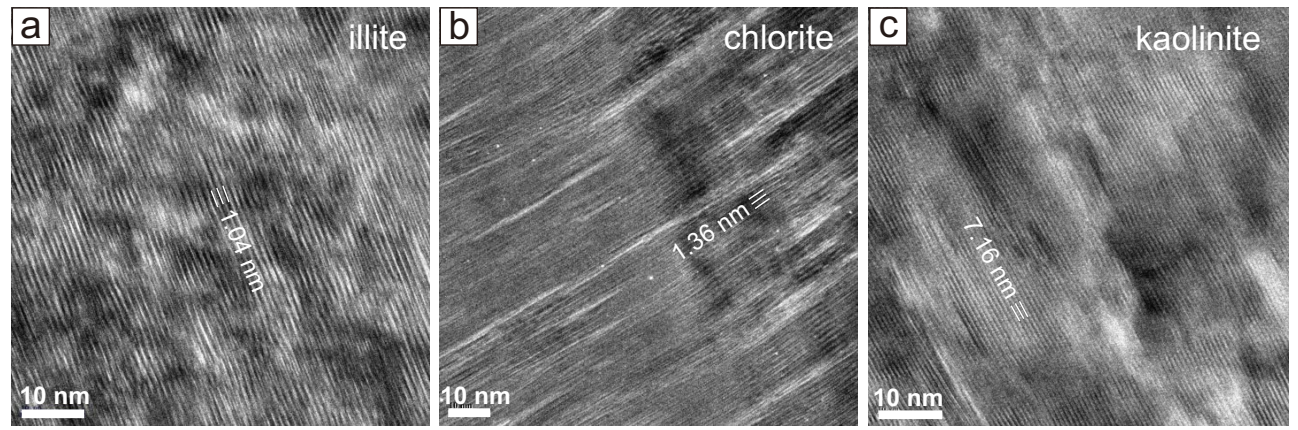

Figure 2. Straight and coherent lattice fringe images of larger compact grains of illite (a), chlorite (b), and kaolinite (c) in Asian dust particles. TEM images of FIB slices.
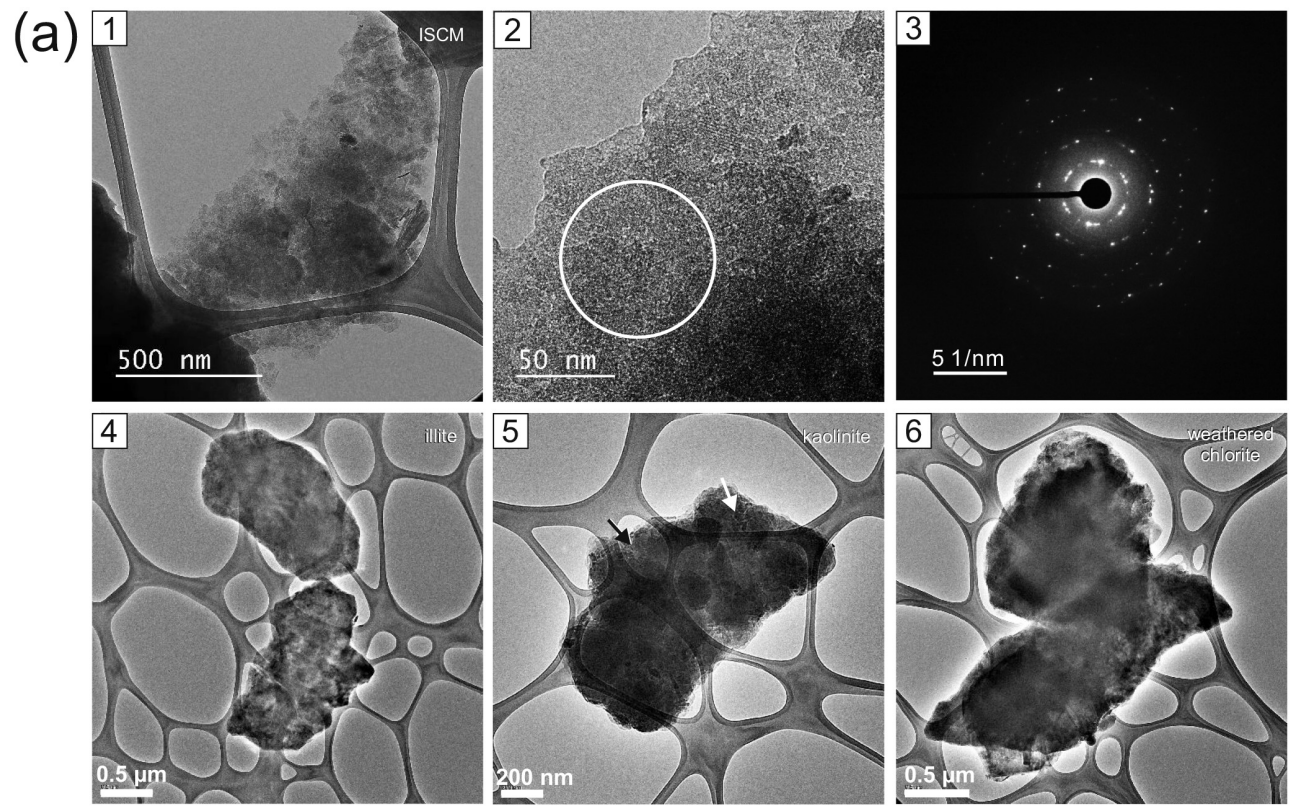

(b)
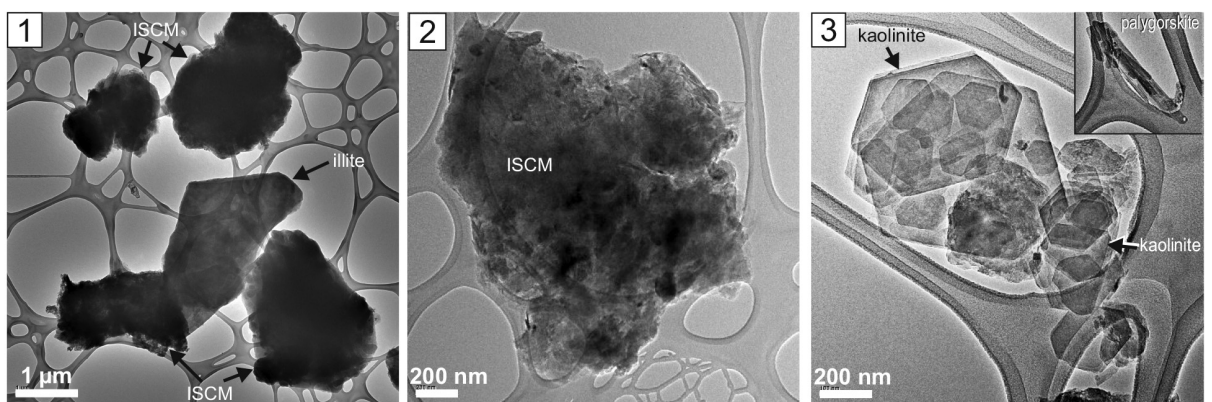

Figure 3. TEM images of clay mineral grains loaded on the micro-grid. Clay mineral grains from Asian dusts, showing ISCM (panel 1), discrete illite (panel 4), kaolinite (panel 5), and chlorite (panel 6) grains. Panel 2 was magnified from Panel 1. Panel 3 is an electron diffraction pattern of the circled area in panel 2 (a). Clay mineral grains from Saharan dusts showing illite (panel 1), ISCM (panels 1 and 2), hexagonal kaolinite (panel 3) and elongated palygorskite (panel 3) grains (b).

mum beam size (ca. $50 \mathrm{~nm}$ ) and the low X-ray counts from the reduced electron dose used to minimize damage by the beam. The Fe content, assuming $14 \mathrm{wt} \%$ of $\mathrm{H}_{2} \mathrm{O}$, was plotted against $\mathrm{K}$ content (Fig. 6). The data points could be cate- gorized into three groups. Group A is clustered in the region bound by ca. $0.5-4.5 \mathrm{wt} \% \mathrm{~K}$ and ca. $2.5-10 \mathrm{wt} \% \mathrm{Fe}$. Group A data were obtained mostly from the sub-parallel groups of thin plates. Groups B and C contained data for thick grains: 
(a)

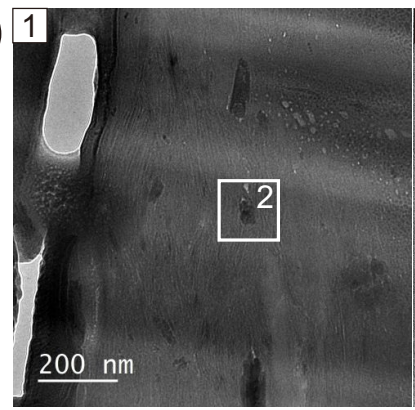

(b)

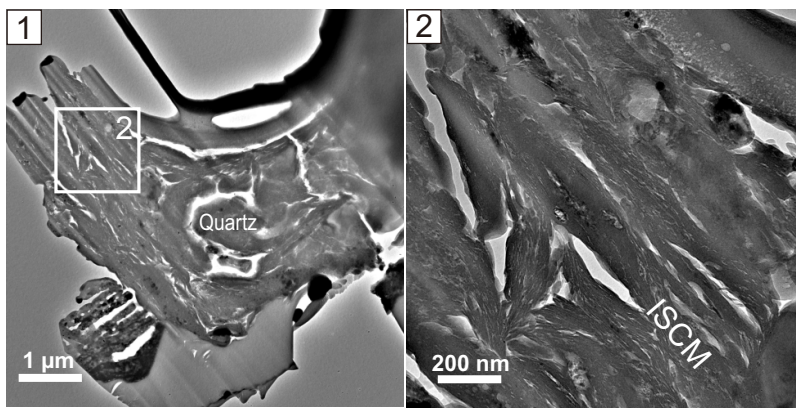

(c)

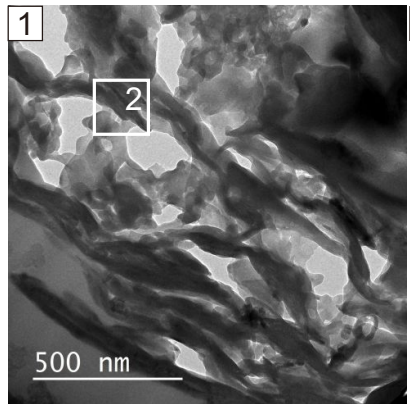

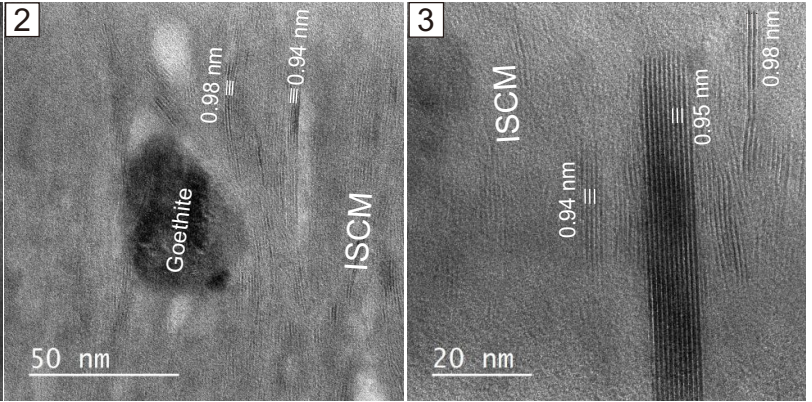
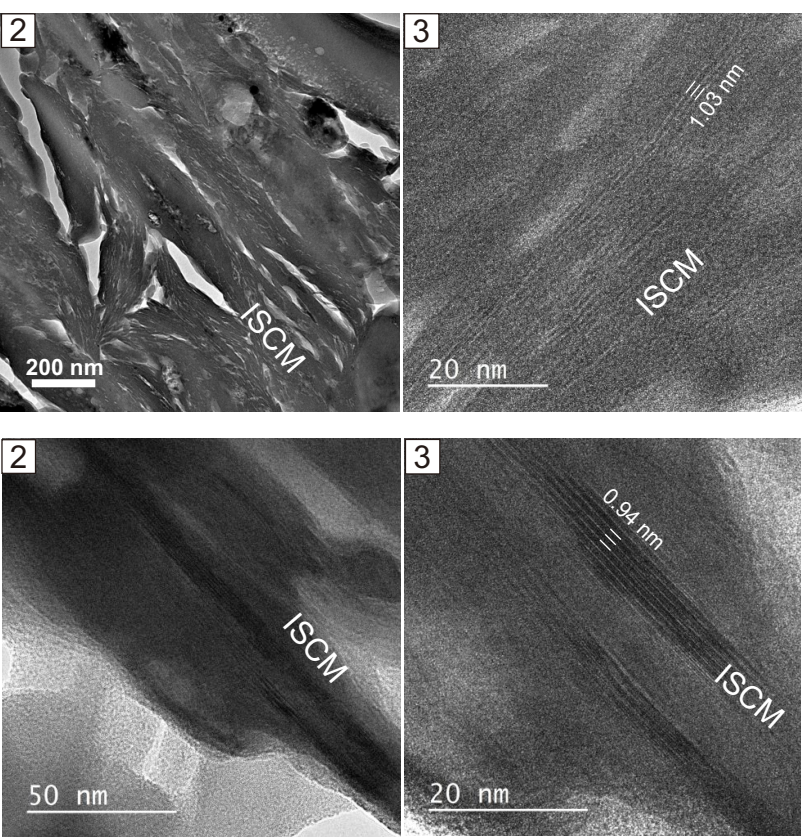

Figure 4. Occurrence of clay minerals in three clay-rich Saharan dust particles (a, b, c). Panel 1 in each particle is a low magnification TEM image of the cross-sectional FIB slice prepared from the original particle. Panel 2 is a TEM image magnified from the TEM image in panel 1. Panel 3 is the lattice fringe image.

(B) high K (ca. 4.5-8.5 wt \%)-low Fe (ca. 0-6 wt \%) and (C) low K (ca. 0-3 wt \%)-high Fe (ca. 10-26 wt \%). The TEMEDXS data from the FIB slices of Asian dust particles are summarized in Table 1.

Group A was considered to represent ISCMs whose intermediate $\mathrm{K}$ content indicates a mixture of nano-thin platelets of illite, smectite, and their mixed-layers. The average ISCM composition of group $\mathrm{A}$ is $\mathrm{K}_{0.25} \mathrm{Ca}_{0.09}\left(\mathrm{Al}_{1.28} \mathrm{Fe}_{0.45}^{3+} \mathrm{Mg}_{0.44} \mathrm{Ti}_{0.01}\right)$ $\left(\mathrm{Al}_{0.50} \mathrm{Si}_{3.50}\right) \mathrm{O}_{10}(\mathrm{OH})_{2}$. The characterization of the nanoscale mixing and mixed layering of the ISCMs can be undertaken by TEM analysis of ISCMs treated with alkyl ammonium ions, which selectively expand smectite layers even under the high vacuum of the TEM chamber (Lagaly, 1994; Jeong et al., 2004). However, the method will require further development before it can be applied to dust particles. The group B was considered to represent discrete illite. The average structural formula of discrete illite in dust particles is $\mathrm{K}_{0.64} \mathrm{Ca}_{0.03}\left(\mathrm{Al}_{1.61} \mathrm{Fe}_{0.22}^{3+} \mathrm{Mg}_{0.22} \mathrm{Ti}_{0.01}\right)\left(\mathrm{Al}_{0.66} \mathrm{Si}_{3.34}\right) \mathrm{O}_{10}(\mathrm{OH})_{2}$.
This formula of group B is consistent with values for the reference illites retrieved from the literature (mean of 24 illite analyses in Table III, Weaver and Pollard, 1975; Table 1.7, Meunier and Velde, 2004) (Fig. 6). The representative formula of reference illites reported in the literature is $\mathrm{K}_{0.77} \mathrm{Ca}_{0.01}\left(\mathrm{Al}_{1.64} \mathrm{Fe}_{0.17} \mathrm{Mg}_{0.20} \mathrm{Ti}_{0.00}\right)$ $\left(\mathrm{Al}_{0.64} \mathrm{Si}_{3.36}\right) \mathrm{O}_{10}(\mathrm{OH})_{2}$. The relative proportions of illite and smectite components could be estimated from the $\mathrm{K}$ contents, because K exists mostly as a fixed cation in the interlayer of illite (Jeong et al., 2004). The relative proportion of illite and smectite components in ISCMs is ca. 35:65 based on the $\mathrm{K}$ contents of the reference illite $(0.77 \mathrm{~K})$ and ISCMs $(0.25 \mathrm{~K})$. The proportion of smectite components is higher than that of the illite component in ISCMs. Group $\mathrm{C}$ could be assigned to the chlorite or K-depleted biotite (vermiculite or biotite-vermiculite mixed-layer) formed during the weathering in the source soils. The average $\mathrm{Fe}$ contents of the ISCMs (5.8 wt \%, group A) are higher than those of illite (2.8 wt \%, group B) and lower than those 

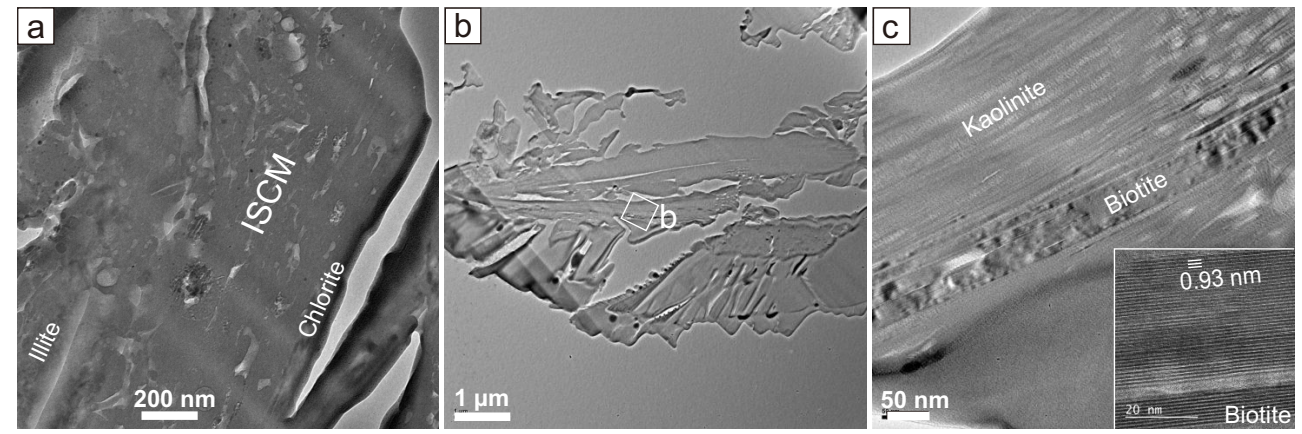

Figure 5. Occurrence of larger compact grains of illite (a), chlorite (a), kaolinite (b, c), and biotite (b, c) in Saharan dust particles.

Table 1. Summary of average chemical compositions of clay mineral grains (wt \%) analyzed by TEM EDXS. $\mathrm{H}_{2} \mathrm{O}$ content of the clay minerals was assumed to be $14 \%$.

\begin{tabular}{lrrrrr|rr}
\hline & \multicolumn{3}{c|}{ Asian dust } & \multicolumn{2}{c}{ Saharan dust } \\
\cline { 2 - 9 } & Micro-grid & $\begin{array}{r}\text { FIB } \\
\text { (whole) }\end{array}$ & $\begin{array}{r}\text { FIB (group } \\
\text { A, ISCMs) }\end{array}$ & $\begin{array}{r}\text { FIB (group } \\
\text { B, illite) }\end{array}$ & $\begin{array}{r}\text { FIB (group } \\
\text { C, chlorite) }\end{array}$ & Micro-grid & FIB \\
\hline$n$ & 514 & 206 & 140 & 27 & 21 & 356 & 116 \\
\hline $\mathrm{Si}$ & 21.4 & 21.7 & 22.7 & 21.5 & 16.0 & 22.4 & 22.4 \\
$\mathrm{Al}$ & 10.7 & 11.5 & 11.1 & 14.0 & 9.6 & 11.9 & 12.9 \\
$\mathrm{Fe}$ & 6.7 & 6.5 & 5.8 & 2.8 & 14.8 & 5.4 & 4.8 \\
$\mathrm{Mg}$ & 2.7 & 2.8 & 2.5 & 1.2 & 6.6 & 2.5 & 2.1 \\
$\mathrm{Ti}$ & 0.2 & 0.1 & 0.1 & 0.1 & 0.1 & 0.2 & 0.1 \\
$\mathrm{~K}$ & 3.9 & 2.4 & 2.2 & 5.8 & 0.9 & 2.2 & 1.9 \\
$\mathrm{Ca}$ & 0.7 & 0.7 & 0.8 & 0.3 & 0.3 & 0.5 & 0.8 \\
\hline
\end{tabular}

of chlorite (14.8 wt \%, group C) (Table 1). One data point plotted near the origin ( $0 \mathrm{wt} \%$ of $\mathrm{K}$ and $\mathrm{Fe})$ indicates the presence of kaolinite. Only three kaolinites were analyzed by EDXS, detecting no Fe.

The EDXS data for the clay mineral grains loaded on the micro-grids, assuming $14 \mathrm{wt} \%$ of $\mathrm{H}_{2} \mathrm{O}$, are presented in Fig. 6 and Table 1. Unlike the grains in the FIB slices, the EDXS analyses of the clay mineral grains on the microgrids could not distinguish between mineralogical types in the mixture. However, the distribution pattern of the data is consistent with that of the FIB slices (Fig. 6). The data indicate a slightly higher $\mathrm{K}$ and $\mathrm{Fe}$ contents compared to the data for FIB slice specimens. This was likely to have originated from the mixture of several clay mineral types in the clay grains loaded on the micro-grids, while clay mineral types could be identified in the FIB slice and separately analyzed by EDXS. In addition, this analysis cannot avoid the ultrafine grains of iron (hydr)oxide phases mixed in the clay grain. Many data points were plotted on the regions of ISCMs $(n=266,52 \%)$ and discrete illite $(n=132,26 \%)$, indicating that the clay minerals $(<2 \mu \mathrm{m})$ in the dusts were dominated by ISCMs and discrete illite with a minor presence of chlorite. The average Fe content of Asian dusts was $7.3 \mathrm{wt} \%$ in $2009(n=159), 6.7 \mathrm{wt} \%$ in $2010(n=100), 6.5 \mathrm{wt} \%$ in $2012(n=105)$, and $6.1 \mathrm{wt} \%$ in $2014(n=150)$. The av- erage Fe content of all the analyzed grains $(n=514)$ was $6.7 \mathrm{wt} \%$. The average chemical composition of the whole data set $(n=514)$ was Si 21.4, Al 10.7, Fe 6.7, Mg 2.7, $\mathrm{Ti} 0.2$, K 3.9, and $\mathrm{Ca} 0.7 \mathrm{wt} \%$ (Table 1). Clay mineral grains from Chinese loess samples, which formed the deposits of ancient Asian dust, were analyzed by the TEM-EDXS of grains loaded on micro-grids (Jeong et al., 2008, 2011). The average chemical composition of the clay minerals in loess samples was Si 21.3, Al 12.3, Fe 6.1, Mg 2.7, Ti 0.1, K 2.6, and $\mathrm{Ca} 0.5$ wt \%, which is remarkably consistent with the composition of our Asian dust samples. Fe that is not incorporated in clay minerals is hosted in Fe (hydr)oxides such as magnetite, goethite, and hematite, and coarse Fe-rich silicate mineral grains such as amphibole, epidote, chlorite, and biotite. Clay-size chlorite can be distinguished from coarsegrained chlorite, as large flakes of chlorite exceeding $10 \mu \mathrm{m}$ in length are commonly found in Asian dust.

\subsubsection{Saharan dust}

EDXS data of clay mineral grains on the micro-grids $(n=356)$ and FIB slices $(n=116)$ are presented in Fig. 6 and summarized in Table 1. The distribution patterns of data show similarity to those of the Asian dust, indicating the presence of ISCMs, discrete illite, and chlorite/biotite. A re- 

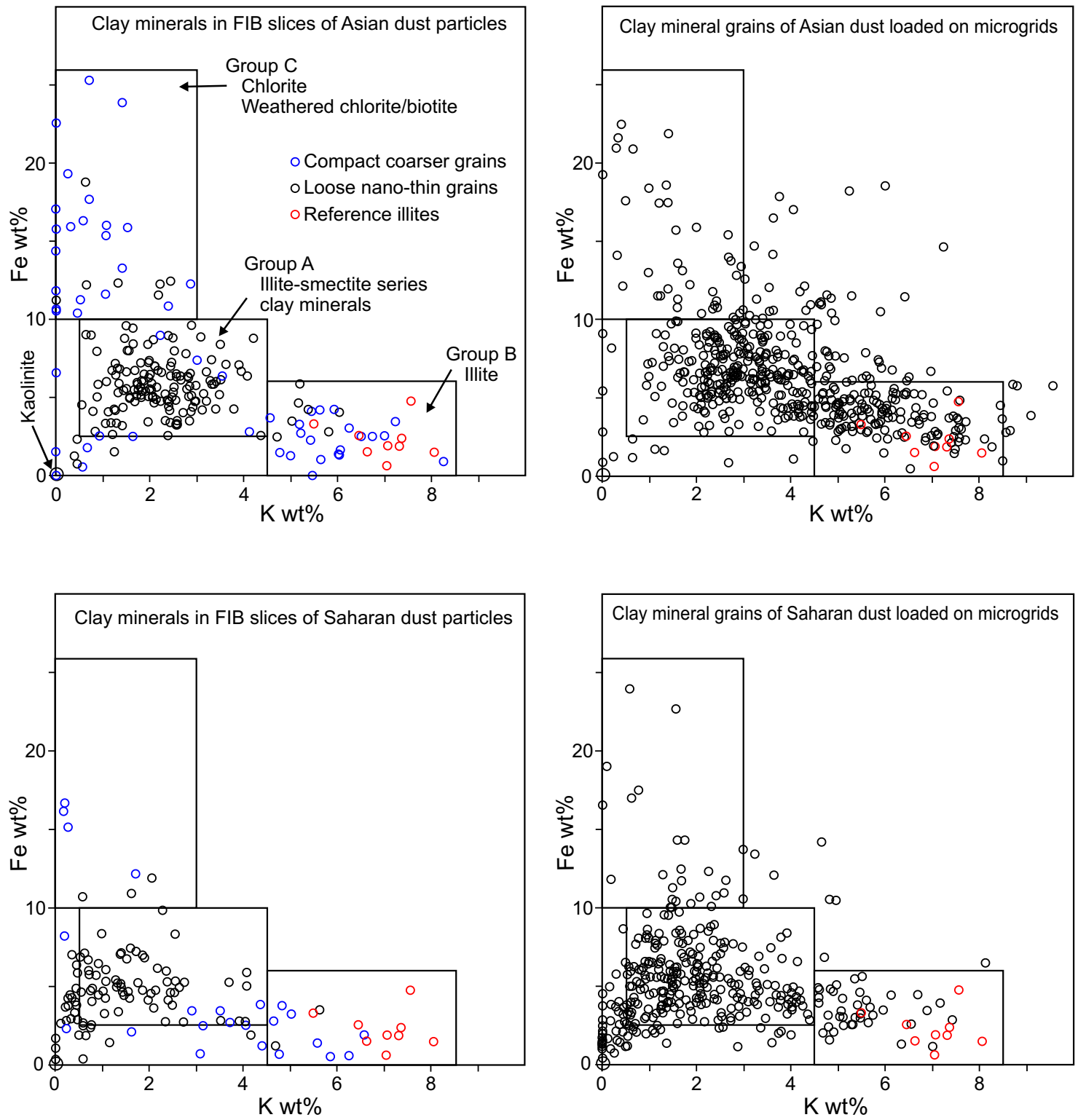

Figure 6. Plots of Fe vs. K from the TEM-EDXS analyses of clay minerals in the cross-sectional FIB slices of dust particles and clay mineral grains loaded on the micro-grids. The boxes indicating groups A, B, and C are drawn on the basis of TEM micro-textures and EDXS data for FIB slices of Asian dust particles.

markable feature of the Saharan dust that differs from Asian dust is that kaolinitic clay mineral grains are more abundant in Saharan dust particles than in Asian dust particles, while chloritic grains are more abundant in Asian dust (Fig. 6). Thus, compared with the chemical composition of Asian dust, $\mathrm{Al}$ was slightly enriched in Saharan dust, while Fe and $\mathrm{K}$ were slightly depleted. $63 \%(n=225)$ of the clay mineral grains on the micro-grid were ISCMs. The average chemical composition of clay mineral grains from the whole data set of micro-grid samples assuming $14 \mathrm{wt} \%$ of $\mathrm{H}_{2} \mathrm{O}$ is Si 22.4, $\mathrm{Al} 11.9$, Fe 5.4, Mg 2.5, Ti 0.2, K 2.2, and $\mathrm{Ca} 0.5$ wt \% (Table 1). The average chemical composition of clay minerals in
Saharan dust is not very different from that in Asian dust. The typical chemical composition of kaolinite is $\mathrm{Al}_{2} \mathrm{Si}_{2} \mathrm{O}_{5}(\mathrm{OH})_{4}$, but with some $\mathrm{Fe}$ replacing $\mathrm{Al}$ in octahedral sites. The average $\mathrm{Fe}$ content from the analyses of 14 kaolinite grains is $1.7 \mathrm{wt} \%$ in Saharan dust.

\subsection{Mineralogical properties of bulk dust}

Mineral compositions determined by XRD analysis are presented in Table 2. Due to the small quantity of samples and low X-ray counts, the data in Table 2 are at best semiquantitative. However, mineralogical differences are evident 
between Asian and Saharan dusts. Although the quantity of each mineral has a large uncertainty, the sum of the mineral groups is more reliable. The mineral compositions of three Asian dusts were compared to the compositions determined by single particle analysis using SEM and EDXS (Table 2). Despite the differences in analytical methods and their semiquantitative nature, the mineral compositions determined by both methods were well matched, supporting the reliability of the mineral composition data for small bulk dust samples presented in this study. ISCMs and discrete thick illite grains could not be distinguished in the XRD method adopted in this study. Thus, sum of ISCMs and discrete illite is presented in Table 2.

A common mineralogical feature in both Asian and Saharan dusts is for the clay minerals to be dominated by ISCMs and illite. This is consistent with TEM-EDXS analysis of clay mineral grains on the micro-grids (Fig. 6). A higher total clay mineral content is a strong mineralogical feature of Saharan dusts, while the quartz and feldspar contents are higher in Asian dust. Of the clay minerals, chlorite contents were higher in Asian dusts, while kaolinite contents were higher in Saharan dusts. XRD analysis of the preferentially oriented specimens of both the Asian and Saharan dusts showed $17 \AA$ peaks of smectite. Although we did not undertake a quantitative analysis, the shoulder near the $10.4 \AA$ peak on the high angle side of the illite (001) peak, which did not disappear following heat treatment at $350^{\circ} \mathrm{C}$, indicated the occurrence of palygorskite as reported by Avila et al. (1997).

\section{Clay minerals as iron carrier}

\subsection{ISCMs}

The TEM-EDXS analyses of FIB slices showed that the Fe contents of ISCMs, illite, and chlorite in Asian dust particles are 5.8, 2.8, and $14.8 \%$, respectively. Although the average $\mathrm{Fe}$ content of ISCMs is lower than chlorite, it is much higher than illite. The contribution of ISCMs to the Fe released by dust is important compared with other clay minerals because they are abundant clay minerals in both the Asian $(52 \%)$ and Saharan $(63 \%)$ dusts, as shown in Table 1 and Fig. 6.

The dissolution of $\mathrm{Fe}$ from silicate minerals depends largely upon physical and chemical factors such as the crystal structure, Fe content, crystallinity, and the surface area of the minerals (Lasaga, 1995; Nagy, 1995). ISCMs are nanothin illite, smectite, and mixed-layered illite-smectite. Thus, the large surface area of Fe-rich ISCMs may lead to an enhanced release of Fe. Baker and Jickells (2006) suggested that the primary control on Fe solubility is the ratio of surface area to volume of dust particles, which decreases during long-range transport due to the preferential removal of larger particles. Our observations confirm the importance of smaller particles, and in particular probably the higher ISCM content of long-range transported particles, which may make a large contribution to Fe release.

\subsection{Chlorite}

Chlorite has received little attention in previous studies. Ferich chlorite is easily decomposed by acids (Ross, 1969; Kodama and Schnitzer, 1973; Brandt et al., 2003; Lowson et al., 2005). In Chinese loess, chlorite is weathered much faster than other silicate minerals (Jeong et al., 2011). Chlorite should be considered in studies of Fe dissolution from mineral dust. Chlorite content of Asian dusts was ca. 4-6\% as determined using single particle analysis (Jeong et al., 2014) and 5-7\% in XRD analysis (this study). In Saharan dusts, the chlorite content was lower at ca. $3 \%$ as determined by XRD analysis (this study). Although the chlorite content in dust is much lower in comparison to ISCMs, the release of Fe from chlorite is likely to be significant because its $\mathrm{Fe}$ content is 3-6 times higher than in the ISCMs and illite. Takahashi et al. (2011) suggested that chlorite could possibly be transformed into soluble ferrihydrite after cloud processing during long-range atmospheric transport. Although we did not determine the oxidation state of $\mathrm{Fe}$, the structural Fe present in chlorite is known to be dominated by Fe(II) (Newman, 1987). In contrast, the structural Fe in the fine ISCMs (dioctahedral illite, smectite, and their mixed layers) is dominated by Fe(III) (Weaver and Pollard, 1975; Newman, 1987). Thus, trioctahedral clay minerals including chlorite may be an important source of soluble Fe(II). Whilst Fe(II) is a bioavailable form of $\mathrm{Fe}$ for microbial organisms (Shaked et al., 2005; Baker and Croot, 2010), its concentration is low due to rapid oxidation to $\mathrm{Fe}(\mathrm{III})$ and low supply rates. Microorganisms therefore have a range of alternative Fe uptake strategies (e.g., Rubin et al., 2011). Fe(II) dissolved from dust is commonly considered to be derived from the photochemical reduction of Fe(III). However, Cwiertny et al. (2008) suggested that $\mathrm{Fe}(\mathrm{II})$-substituted aluminosilicates may be an important alternative source of soluble $\mathrm{Fe}(\mathrm{II})$, particularly after the reaction of dust with atmospheric acids. Chlorite grains occur in a diverse size range, from individual large flaky particles of several micrometers (Jeong, 2008; Jeong and Nousiainen, 2014) to nano-thin platelets mixed with nano-thin ISCMs (Fig. 2b-3). Nano-thin chlorite plates are probably most effective in releasing $\mathrm{Fe}$ from dust particles following reaction with atmospheric acids.

\section{Implications to the evaluation of iron supply to oceans}

Global dust distributions and oceanic Fe deposition are modeled assuming the $\mathrm{Fe}$ content of bulk dust being equivalent to the average Fe content of the Earth crust (3.5\%) (Mahowald et al., 2005, 2009). A recent modeling study on Fe supply to the oceans progressed to include dust mineralogy and $\mathrm{Fe}$ content of clay minerals (Johnson and Meskhidze, 2013). 
Table 2. Semi-quantitative mineral compositions (wt \%) of Asian and Saharan dusts determined by XRD analysis with mineral compositions of Asian dusts determined by SEM single particle analysis for comparison.

\begin{tabular}{|c|c|c|c|c|c|c|c|c|}
\hline & \multicolumn{5}{|c|}{ Asian dust XRD } & \multicolumn{3}{|c|}{ Saharan dust XRD } \\
\hline & $\begin{array}{r}18 \mathrm{Mar} \\
2014\end{array}$ & $\begin{array}{r}31 \mathrm{Mar} \\
2012\end{array}$ & $\begin{array}{r}20 \mathrm{Mar} \\
2010\end{array}$ & $\begin{array}{r}16-17 \\
\text { Mar } 2009\end{array}$ & Average & $\begin{array}{r}18-23 \\
\operatorname{Jan} 2008\end{array}$ & $\begin{array}{r}28-31 \\
\operatorname{Dec} 2007\end{array}$ & Average \\
\hline ISCMs/illite & 60 & 42 & 50 & 42 & 49 & 71 & 74 & 72 \\
\hline Kaolinite & 1 & 3 & 4 & 4 & 3 & 8 & 4 & 6 \\
\hline Chlorite & 3 & 6 & 7 & 7 & 6 & 3 & 3 & 3 \\
\hline Total clay & 64 & 52 & 61 & 53 & 57 & 81 & 81 & 81 \\
\hline Quartz & 14 & 23 & 15 & 13 & 16 & 10 & 7 & 8 \\
\hline Plagioclase & 11 & 15 & 10 & 12 & 12 & 2 & 2 & 2 \\
\hline K-feldspar & 0 & 6 & 2 & 1 & 2 & 1 & 1 & 1 \\
\hline Amphibole & 0 & 1 & 2 & 2 & 1 & 0 & 0 & 0 \\
\hline Calcite & 5 & 2 & 5 & 6 & 5 & 2 & 3 & 2 \\
\hline Gypsum & 6 & 2 & 6 & 13 & 6 & 4 & 6 & 5 \\
\hline \multirow[t]{2}{*}{ Total } & 100 & 100 & 100 & 100 & 100 & 100 & 100 & 100 \\
\hline & \multicolumn{5}{|c|}{$\begin{array}{c}\text { SEM single particle analysis } \\
\text { (Jeong et al., 2014, and this study)* }\end{array}$} & & & \\
\hline ISCMs/illite & 54 & 48 & 54 & & 52 & & & \\
\hline Kaolinite & 1 & 3 & 2 & & 2 & & & \\
\hline Chlorite & 2 & 4 & 6 & & 4 & & & \\
\hline Total clay & 58 & 55 & 62 & & 58 & & & \\
\hline Quartz & 19 & 21 & 17 & & 19 & & & \\
\hline Plagioclase & 11 & 11 & 10 & & 11 & & & \\
\hline K-feldspar & 4 & 5 & 3 & & 4 & & & \\
\hline Amphibole & 1 & 1 & 0 & & 1 & & & \\
\hline Calcite & 7 & 7 & 6 & & 7 & & & \\
\hline Gypsum & 0 & 1 & 1 & & 1 & & & \\
\hline Total & 100 & 100 & 100 & & 100 & & & \\
\hline
\end{tabular}

Mineral compositions were predicted from available soil data (Claquin et al., 1999; Nikovic et al., 2012; Journet et al., 2014). However, mineralogical and chemical compositions of world soils are certainly variable and poorly constrained. In particular, the analytical data on the chemical composition (including $\mathrm{Fe}$ ) of fine clay minerals in local soils are hard to find in literature because the analytical measurements are as difficult as the analysis of clay minerals in dust. The modeling study on the Fe supply to global oceans by Johnson and Meskhidze (2013) highlighted the importance of mineralogical data of dust in the deposition of dissolved $\mathrm{Fe}$ to the global oceans. They adopted mineral compositions of dust derived from a soil database of Nikovic et al. (2012) and Fe content of a commercial illite reported by Paris et al. (2011). However, their model sensitivity analysis showed large variations of dissolved $\mathrm{Fe}$ fluxes to the oceans, associated with the uncertainty in the dust mineralogy and Fe content of constituent minerals. They emphasized that realistic data of dust mineralogy and Fe content within individual Fe-containing minerals are essential for the improvement of the description of the Fe biogeochemical cycles in climate models. Although the chemical analysis of clay minerals in individual dust particles as carried out in this study is challenging, detailed analysis of representative global dust samples is likely an efficient approach for obtaining information on Fe mineralogy in dust. Long-range transported dust has the average mineralogical and chemical properties of fine soil particles lifted from the wide source regions of varying soil mineralogy. In addition, the mineral composition and chemistry in dust from the major source regions do not show significant inter-event and annual changes (Jeong, 2008). Further analytical works for dust samples transported over long distances from major source regions will allow the establishment of realistic mineralogical database for the evaluation of $\mathrm{Fe}$ inputs to the remote ocean. 


\section{Summary and conclusions}

Mineral composition of bulk dust samples, Fe content of constituent minerals, and their grain sizes form essential data for the evaluation of Fe supply to remote surface oceans. Particularly, the properties of clay minerals are important because of their abundance in mineral dust and high Fe contents, relative to other silicates. We presented for the first time mineralogical and chemical data of clay minerals in individual dust particles from several Asian and Saharan dust samples, following analyses by TEM and EDXS. The total clay content of Asian dusts determined by XRD analysis was lower than that of Saharan dusts. TEM analysis of thin cross-sectional slices of the dust particles revealed that nano-thin platelets of ISCMs (illite, smectite, and illite-smectite mixed layers) were most abundant in association with illite, chlorite, and kaolinite occurring as thicker plates. Asian dusts were enriched with chlorite relative to Saharan dust, while Saharan dusts were relatively enriched with kaolinite. Kaolinite in Saharan dust occurred as hexagonal plates that were better crystallized than in Asian dust. The average Fe content of the ISCMs in Asian dusts as determined by EDXS was $5.8 \%$ assuming $14 \% \mathrm{H}_{2} \mathrm{O}$, while the contents of illite and chlorite were 2.8 and $14.8 \%$, respectively. The average Fe content of the EDXS data of the clay mineral grains dispersed and loaded on the micro-grids was 6.7 and $5.4 \%$ in Asian and Saharan dusts, respectively. The Fe dissolution from clay minerals is thought to be enhanced by the nanocrystallinity of ISCMs; furthermore, Fe-rich chlorite susceptible to acids may enhance dissolution of Fe. The establishment of realistic mineralogical data sets from global dust samples is important to reduce the uncertainty in the prediction of iron inputs to oceans using geochemical and meteorological models.

\section{The Supplement related to this article is available online at doi:10.5194/acp-14-12415-2014-supplement.}

Acknowledgements. This study was funded by the National Research Foundation of Korea grant NRF-2011-0028597. We thank the anonymous referees for constructive comments that improved the manuscript.

Edited by: Y. Rudich

\section{References}

Aguilar-Islas, A. M., Wu, J., and Rember, R.: Dissolution of aerosol-derived iron in seawater: leach solution chemistry, aerosol type, and colloidal iron fraction, Mar. Chem., 120, 25-33, doi:10.1016/j.marchem.2009.01.011, 2010.
Avila, A., Queralt-Mitjans, I., and Alacón, M.: Mineralogical composition of African dust delivered by red rains over northeastern Spain, J. Geophys. Res., 102, 21977-21996, 1997.

Baker, A. R. and Croot, P. L.: Atmospheric and marine controls on aerosol iron solubility in seawater, Mar. Chem., 120, 4-13, doi:10.1016/j.marchem.2008.09.003, 2010.

Baker, A. R. and Jickells, T. D.: Mineral particle size as a control on aerosol iron solubility, Geophys. Res. Lett., 33, L17608, doi:10.1029/2006GL026557, 2006.

Bopp, L., Kohfeld, K. E., and Quere, C. L.: Dust impact on marine biota and atmospheric $\mathrm{CO}_{2}$ during glacial periods, Paleoceanography, 18, 1046, doi:10.1029/2002PA000810, 2003.

Boyd, P. W., Watson, A. J., Law, C. S., Abraham, E. R., Trull, T., Murdoch, R., Bakker, D. C. E., Bowie, A. R., Buesseler, K. O., Chang, H., Charette, M., Croot, P., Downing, K., Frew, R., Gall, M., Hadfield, M., Hall, J., Harvey, M., Jameson, G., LaRoche, J., Liddicoat, M., Ling, R., Maldonado, M. T., McKay, R. M., Nodder, S., Pickmere, S., Pridmore, R., Rintoul, S., Safi, K., Sutton, P., Strzepek, R., Tanneberger, K., Turner, S., Waite, A., and Zeldis, J.: A mesoscale phytoplankton bloom in the polar Southern Ocean stimulated by iron fertilization, Nature, 407, 695-702, 2000.

Boyd, P. W., Law, C. S., Wong, C. S., Nojiri, Y., Tsuda, A., Levasseur, M., Takeda, S., Rivkin, R., Harrison, P. J., Strzepek, R., Gower, J., McKay, R. M., Abraham, E., Arychuk, M., BarwellClarke, J., Crawford, W., Hale, M., Harada, K., Johnson, K., Kiyosawa, H., Kudo, I., Marchetti, A., Miller, W., Needoba, J., Nishioka, J., Ogawa, H., Page, J., Robert, M., Saito, H., Sastri, A., Sherry, N., Soutar, T., Sutherland, N., Taira, Y., Whitney, F., Wong, S.-K. E., and Yoshimura, T.: The decline and fate of an iron-induced subarctic phytoplankton bloom, Nature, 428, 549-553, doi:10.1038/nature02437, 2004.

Brandt, F., Bosbach, D., Krawczyk-Bärsch, E., Arnold, T., and Bernhard, G.: Chlorite dissolution in the acid pH-range: A combined microscopic and macroscopic approach, Geochim. Cosmochim. Ac., 67, 1451-1461, 2003.

Buck, C. S., Landing, W. M., Resing, J. A., and Lebon, G. T.: Aerosol iron and aluminum solubility in the northwest Pacific Ocean: results from the 2002 IOC cruise, Geochem. Geophys. Geosyst., 7, Q04M07, doi:10.1029/2005GC000977, 2006.

Buck, C. S., Landing, W. M., and Resing, J. A.: Particle size and aerosol iron solubility: A high-resolution analysis of Atlantic aerosols, Mar. Chem., 120, 14-24, 2010.

Carpenter, L. J., Fleming, Z. L., Read, K. A., Lee, J. D., Moller, S. J., Hopkins, J. R., Purvis, R. M., Lewis, A. C., Müller, K., Heinold, B., Herrmann, H., Wadinga Fomba, K., van Pinxteren, D., Müller, C., Tegen, I., Wiedensohler, A., Müller, T., Niedermeier, N., Achterberg, E. P., Patey, M. D., Kozlova, E. A., Heimann, M., Heard, D. E., Plane, J. M. C., Mahajan, A., Oetjen, H., Ingham, T., Stone, D., Whalley, L. K., Evans, M. J., Pilling, M. J., Leigh, R. J., Monks, P. S., Karunaharan, A., Vaughan, S., Arnold, S. R., Tschritter, J., Pöhler, D., Frieß, U., Holla, R., Mendes, L. M., Lopez, H., Faria, B., Manning, A. J., and Wallace, D. W. R.: Seasonal characteristics of tropical marine boundary layer air measured at the Cape Verde Atmospheric Observatory, J. Atmos. Chem., 67, 87-140, doi:10.1007/s10874-0119206-1, 2010. 
Claquin, T., Schulz, M., and Balkanski, Y.: Modeling the mineralogy of atmospheric dust sources, J. Geophys. Res., 104, 22243-22256, 1999.

Cliff, G. and Lorimer, G. W.: The quantitative analysis of thin specimens, J. Microsc., 103, 203-207, 1975.

Cwiertny, D. M., Young, M. A., and Grassian, V. H.: Chemistry and photochemistry of mineral dust aerosol, Annu. Rev. Phys. Chem., 59, 27-51, 2008.

Desboeufs, K. V., Lonso, R., and Colin, J. L.: Factors influencing aerosol solubility during cloud processes, Atmos. Environ., 35, 3529-3537, 2001.

Dong, H., Peacor, D. R., and Murphy, S. F.: TEM study of progressive alteration of igneous biotite to kaolinite throughout a weathered soil profile, Geochim. Cosmochim. Ac., 62, 1881-1888, 1998.

Falkovich, A. H., Ganor, E., Levin, Z., Formenti, P., and Rudich, Y.: Chemical and mineralogical analysis of individual mineral dust particles, J. Geophys. Res., 106, 18029-18036, 2001.

Formenti, P., Schütz, L., Balkanski, Y., Desboeufs, K., Ebert, M., Kandler, K., Petzold, A., Scheuvens, D., Weinbruch, S., and Zhang, D.: Recent progress in understanding physical and chemical properties of African and Asian mineral dust, Atmos. Chem. Phys., 11, 8231-8256, doi:10.5194/acp-11-8231-2011, 2011.

Fu, H., Cwiertny, D. M., Carmichael, G. R., Scherer, M. M., and Grassian, V. H.: Photoreductive dissolution of Fe-containing mineral dust particles in acidic media, J. Geophys. Res., 115, D11304, doi:10.1029/2009JD012702, 2010.

Glaccum, R. A. and Prospero, J. M.: Saharan aerosols over the tropical north Atlantic-Mineralogy, Mar. Geol., 37, 295-321, 1980.

Guieu, C., Bonnet, S., and Wagener, T.: Biomass burning as a source of dissolved iron to the ocean?, Geophys. Res. Lett. 32, L19608, doi:10.1029/2005GL022962, 2005.

Hand, J. L., Mahowald, N. M., Chen, Y., Siefert, R. L., Luo, C., Subramaniam, A., and Fung, I.: Estimates of atmosphericprocessed soluble iron from observations and a global mineral aerosol model: Biogeochemical implications, J. Geophys. Res., 109, D17205, doi:10.1029/2004JD004574, 2004.

Ito, A. and Feng, Y.: Role of dust alkalinity in acid mobilization of iron, Atmos. Chem. Phys., 10, 9237-9250, doi:10.5194/acp-109237-2010, 2010.

Jeong, G. Y.: The dependence of localized crystallization of halloysite and kaolinite on primary minerals in the weathering profile of granite, Clay. Clay Miner., 48, 196-203, 2000.

Jeong, G. Y.: Bulk and single-particle mineralogy of Asian dust and a comparison with its source soils, J. Geophys. Res., 113, D02208, doi:10.1029/2007JD008606, 2008.

Jeong, G. Y. and Kim, H. B.: Mineralogy, chemistry, and formation of oxidized biotite in the weathering profile of granitic rocks, Am. Mineral., 88, 352-364, 2003.

Jeong, G. Y. and Nousiainen, T.: TEM analysis of the internal structures and mineralogy of Asian dust particles and the implications for optical modeling, Atmos. Chem. Phys., 14, 7233-7254, doi:10.5194/acp-14-7233-2014, 2014

Jeong, G. Y., Yoon, H. I., and Lee, S. Y.: Chemistry and microstructures of clay particles in smectite-rich shelf sediments, South Shetland Islands, Antarctica, Mar. Geol., 209, 19-30, 2004.

Jeong, G. Y., Hillier, S., and Kemp, R. A.: Quantitative bulk and single-particle mineralogy of a thick Chinese loess-paleosol sec- tion: implications for loess provenance and weathering, Quaternary Sci. Rev., 37, 1271-1287, 2008.

Jeong, G.Y., Hillier, S., and Kemp, R. A.: Changes in mineralogy of loess-paleosol sections across the Chinese Loess Plateau, Quaternary Res., 75, 245-255, 2011.

Jeong, G. Y., Kim, J. Y., Seo, J., Kim, G. M., Jin, H. C., and Chun, Y.: Long-range transport of giant particles in Asian dust identified by physical, mineralogical, and meteorological analysis, Atmos. Chem. Phys., 14, 505-521, doi:10.5194/acp-14-505-2014, 2014.

Jickells, T. D. and Spokes, L. J.: Atmospheric iron inputs to the ocean, in: Biogeochemistry of Iron in Seawater, edited by: Turner, D. and Hunter, K. A., John Wiley, Hoboken, N. J., 85-121, 2001.

Jickells, T. D., An, Z. S., Andersen, K. K., Baker, A. R., Bergametti, G., Brooks, N., Cao, J. J., Boyd, P. W., Duce, R. A., Hunter, K. A., Kawahata, H., Kubilay, N., laRoche, J., Liss, P. S., Mahowald, N., Prospero, J. M., Ridgwell, A. J., Tegen, I., and Torres, R.: Global Iron Connections Between Desert, Dust, Ocean Biogeochemistry, and Climate, Science, 308, 67-71, 2005.

Johnson, M. S. and Meskhidze, N.: Atmospheric dissolved iron deposition to the global oceans: effects of oxalate-promoted $\mathrm{Fe}$ dissolution, photochemical redox cycling, and dust mineralogy, Geosci. Model Dev., 6, 1137-1155, doi:10.5194/gmd-6-11372013, 2013.

Johnson, M. S., Meskhidze, N., Solmon, F., Gassó, S., Chuang,P. Y., Gaiero, D. M., Yantosca, R. M., Wu, S., Wang, Y., and Carouge, C.: Modeling dust and soluble iron deposition to the South Atlantic Ocean, J. Geophys. Res., 115, D15202, doi:10.1029/2009JD013311, 2010.

Journet, E., Desboeufs, K. V., Caquineau, S., and Colin, J.-L.: Mineralogy as a critical factor of dust iron solubility, Geophys. Res. Lett. 35, L07805, doi:10.1029/2007GL031589, 2008.

Journet, E., Balkanski, Y., and Harrison, S. P.: A new data set of soil mineralogy for dust-cycle modeling, Atmos. Chem. Phys., 14, 3801-3816, doi:10.5194/acp-14-3801-2014, 2014.

Kodama, H. and Schnitzer, M.: Dissolution of chlorite minerals by fulvic acid, Can. J. Soil Sci., 53, 240-243, 1973.

Korea Meteorological Administration (KMA), available at: http:// web.kma.go.kr/eng/weather/asiandust/timeseries.jsp, last access: 30 March 2014.

Lagaly, G.: Layer charge determination by alkylammonium ions, in: Layer Charge Characteristics of 2:1 Silicate Clay Minerals, edited by: Mermut, A. R., The Clay Minerals Society, Boulder, CO, 80-103, 1994.

Lasaga, A. C.: Fundamental approaches in describing mineral dissolution and precipitation rates, Rev. Mineral., 31, 23-86, 1995.

Lowson, R. T., Comarmond, J., Rajaratnam, G., and Brown, P. L.: The kinetics of the dissolution of chlorite of $\mathrm{pH}$ and at $25^{\circ} \mathrm{C}$, Geochim. Cosmochim. Ac., 69, 1687-1699, 2005.

Mahowald, N. M., Baker, A. R., Bergametti, G., Brooks, N., Duce, R. A., Jickells, T. D., Kubilay, N., Prospero, J. M., and Tegen, I.: The atmospheric global dust cycle and iron inputs to the ocean, Global Biogeochem. Cy., 19, GB4025, doi:10.1029/2004GB002402, 2005.

Mahowald, N. M., Engelstaedter, S., Luo, C., Sealy, A., Artaxo, P., Benitez-Nelson, C., Bonnet, S., Chen, Y., Chuang, P. Y., Cohen, D. D., Dulac, F., Herut, B., Johansen, A. M., Kubilay, N., Losno, R., Maenhaut, W., Paytan, A., Prospero, J. M., Shank, L. M., and 
Siefert, R. L.: Atmospheric iron deposition: global distribution, variability, and human perturbations. Annu. Rev. Mar. Sci., 1, 245-278, 2009.

Mehra, O. P. and Jackson, M. J.: Iron oxide from soils and clays by a dithionite system buffered with sodium bicarbonate, Clay. Clay Miner., 7, 317-327, 1960.

Meskhidze, N., Chameides, W. L., Nenes, A., and Chen, G.: Iron mobilization in mineral dust: Can anthropogenic $\mathrm{SO}_{2}$ emissions affect ocean productivity?, Geophys. Res. Lett., 30, 2085, doi:10.1029/2003GL018035, 2003.

Meskhidze, N., Chameides, W. L., and Nenes, A.: Dust and pollution: a recipe for enhanced ocean fertilization, J. Geophys. Res., 110, D03301, doi:10.1029/2004JD005082, 2005.

Meunier, A. and Velde, B.: Illite, Springer, Berlin, 2004.

Moore, C. M., Mills, M. M., Achterberg, E. P., Geider, R. J., LaRoche, J., Lucas, M. I., McDonagh, E. L., Pan, X., Poulton, A. J., Rijkenberg, M. J. A., Suggett, D. J., Ussher, S. J., and Woodward, E. M. S.: Large-scale distribution of Atlantic nitrogen fixation controlled by iron availability, Nat. Geosci., 2, 867-871, 2009.

Nagy, K. L.: Dissolution and precipitation kinetics of sheet silicates, Rev. Mineral., 31, 173-273, 1995.

Newman, A. C. D.: The chemical constitution of clays, in: Chemistry of Clays and Clay Minerals, edited by: Newman, A. C. D., Mineralogical Society, London, 1-128, 1987.

Nickovic, S., Vukovic, A., Vujadinovic, M., Djurdjevic, V., and Pejanovic, G.: Technical Note: High-resolution mineralogical database of dust-productive soils for atmospheric dust modeling, Atmos. Chem. Phys., 12, 845-855, doi:10.5194/acp-12-8452012, 2012.

Paris, R., Desboeufs, K. V., Formenti, P., Nava, S., and Chou, C.: Chemical characterisation of iron in dust and biomass burning aerosols during AMMA-SOP0/DABEX: implication for iron solubility, Atmos. Chem. Phys., 10, 4273-4282, doi:10.5194/acp10-4273-2010, 2010.

Paris, R., Desboeufs, K. V., and Journet, E.: Variability of dust iron solubility in atmospheric waters: investigation of the role of oxalate organic complexation, Atmos. Environ., 45, 6510-6517, 2011.

Raiswell, R. and Canfield, D. E.: The iron biogeochemical cycle past and present, Geochemical Perspectives, 1, 1-220, 2012.

Ross, G. J.: Acid dissolution of chlorites: release of magnesium, iron and aluminium and mode of acid attack, Clay. Clay Miner., 17, 347-354, 1969.

Rubin, M., Berman-Frank, I., and Shaked, Y.: Dust- and mineraliron utilization by the marine dinitrogen-fixer Trichodesmium, Nat. Geosci., 4, 529-534, doi:10.1038/NGEO1181, 2011.

Schlosser, C., Klar, J. K., Wake, B. D., Snow, J. T., Honey, D. J., Woodward, E. M. S., Lohan, M. C., Achterberg, E. P., and Moore, C. M.: Seasonal ITCZ migration dynamically controls the location of the (sub)tropical Atlantic biogeochemical divide, P. Natl. Acad. Sci. USA, 111, 1438-1442, doi:10.1073/pnas.1318670111, 2014.

Shaked, Y., Kustka, A. B., and Morel, F. M. M.: A general kinetic model for iron acquisition by eukaryotic phytoplankton, Limnol. Oceanogr., 50, 872-882, 2005.
Shi, Z., Shao, L., Jones, T. P., and Lu, S.: Microscopy and mineralogy of airborne particles collected during severe dust storm episodes in Beijing, China, J. Geophys. Res., 110, D01303, doi:10.1029/2004JD005073, 2005.

Shi, Z. B., Krom, M. D., Bonneville, S., Baker, A. R., Jickells, T. D., and Benning, L. G.: Formation of iron nanoparticles and increase in iron reactivity in mineral dust during simulated cloud processing, Environ. Sci. Technol., 43, 6592-6596, doi:10.1021/es901294g, 2009.

Shi, Z. B., Woodhouse, M. T., Carslaw, K. S., Krom, M. D., Mann, G. W., Baker, A. R., Savov, I., Fones, G. R., Brooks, B., Drake, N., Jickells, T. D., and Benning, L. G.: Minor effect of physical size sorting on iron solubility of transported mineral dust, Atmos. Chem. Phys., 11, 8459-8469, doi:10.5194/acp-11-84592011, 2011.

Sholkovitz, E. R., Sedwick, P. N., Church, T. M., Baker, A. R., and Powell, C. F.: Fractional solubility of aerosol iron: Synthesis of a global-scale data set, Geochim. Cosmochim. Ac., 89, 173-189, 2012.

Siefert, R. L., Pehkonen, S. O., Erel, Y., and Hoffmann, M. R.: Iron photochemistry of aqueous suspensions of ambient aerosol with added organic acids, Geochim. Cosmochim. Ac., 58, 3271-3279, 1994.

Środoń, J.: Nature of mixed-layer clays and mechanisms of their formation and alteration, Annu. Rev. Earth Pl. Sc., 27, 19-53, 1999.

Tagliabue, A., Bopp, L., Dutay, J. -C., Bowie, A. R., Chever, F., Jean-Baptiste, P., Bucciarelli, E., Lannuzel, D., Remenyi, T., Sarthou, G., Aumont, O., Gehlen, M., and Jeandel, C.: Hydrothermal contribution to the oceanic dissolved iron inventory, Nat. Geosci., 3, 252-256, 2010.

Takahashi, Y., Higashi, M., Furukawa, T., and Mitsunobu, S.: Change of iron species and iron solubility in Asian dust during the long-range transport from western China to Japan, Atmos. Chem. Phys., 11, 11237-11252, doi:10.5194/acp-1111237-2011, 2011.

Trapp, J. M., Millero, F. J., and Prospero, J. M.: Trends in the solubility of iron in dust-dominated aerosols in the equatorial Atlantic trade winds: importance of iron speciation and sources, Geochem. Geophys. Geosys., 11, Q03014, doi:10.1029/2009GC002651, 2010.

Weaver, C. E.: Clays, muds, and shales, Elsevier, Amsterdam, 1989.

Weaver, C. E. and Pollard, L. D.: The chemistry of clay minerals, Elsevier, Amsterdam, 1975.

Williams, D. B. and Carter, C. B.: Transmission electron microscopy, Springer, New York, 2009.

Zhuang, G., Yi, Z., Duce, R. A., and Brown, P. R.: Chemistry of iron in marine aerosols, Global Biogeochem. Cy., 6, 161-173, 1992. 